\title{
Hemodynamic profiles related to circulatory shock in cardiac care units
}

\section{Perfiles hemodinámicos relacionados con el choque circulatorio en unidades de cuidados cardiacos}

\author{
Jesus A. Gonzalez-Hermosillo ${ }^{1}$, Ricardo Palma-Carbajal ${ }^{\text {* }}$, Gustavo Rojas-Velasco², \\ Ricardo Cabrera-Jardines ${ }^{3}$, Luis M. Gonzalez-Galvan4, Daniel Manzur-Sandoval2, \\ Gian M. Jiménez-Rodriguez ${ }^{5}$ y Willian A. Ortiz-Solis ${ }^{1}$
}

${ }^{1}$ Departamento de Cardiología; 2 Unidad de Terapia Intensiva Cardiovascular, Instituto Nacional de Cardiología Ignacio Chavez; ${ }^{3}$ Medicina Interna, Hospital Ángeles del Pedregal; ${ }^{4}$ Escuela de posgrados en Sanidad Naval, Universidad Naval; ${ }^{5}$ Cardiología intervencionista, Instituto Nacional de Cardiología Ignacio Chavez. Ciudad de México, México

\begin{abstract}
One-third of the population in intensive care units is in a state of circulatory shock, whose rapid recognition and mechanism differentiation are of great importance. The clinical context and physical examination are of great value, but in complex situations as in cardiac care units, it is mandatory the use of advanced hemodynamic monitorization devices, both to determine the main mechanism of shock, as to decide management and guide response to treatment, these devices include pulmonary flotation catheter as the gold standard, as well as more recent techniques including echocardiography and pulmonary ultrasound, among others. This article emphasizes the different shock mechanisms observed in the cardiac care units, with a proposal for approach and treatment.
\end{abstract}

Key words: Circulatory shock. Hemodynamic monitorization. Echocardiography. Pulmonary ultrasound.

\section{Resumen}

Un tercio de la población de pacientes en unidades de cuidados intensivos se encuentran en choque circulatorio, el identificarlo y determinar su mecanismo de manera rápida y eficaz es de gran importancia. El contexto clínico y el examen físico son de gran utilidad, sin embargo existen situaciones de alta complejidad en las que se requiere del uso de las distintas modalidades de monitorización hemodinámica avanzada, tanto para determinar la causa, como para decidir el manejo y guiar respuesta al tratamiento, incluyendo el catéter de flotación pulmonar como gold standard, así como técnicas más recientes incluyendo ecocardiografía y ultrasonido pulmonar, entre otros. Este artículo enfatiza los distintos mecanismos de choque observados en las unidades de cuidados cardiacos, con propuesta de abordaje y tratamiento.

Palabras clave: Choque circulatorio. Monitorización hemodinámica. Ecocardiografía. Ultrasonido pulmonar.

\section{Correspondencia:}

*Ricardo Palma-Carbajal

Unidad de terapia intensiva cardiovascular

Instituto Nacional de Cardiología Ignacio Chavez

Ciudad de México, México

Fecha de recepción: 13-12-2018

Fecha de aceptación: 19-07-2019

E-mail: dr.ricardopalma@gmail.com

DOI: 10.24875/ACM.19000016
Disponible en internet: 10-09-2019 Arch Cardiol Mex. 2020;90(1):47-54 www.archivoscardiologia.com 2604-7063/@ 2019 Instituto Nacional de Cardiología Ignacio Chávez. Publicado por Permanyer. Este es un artículo open access bajo la licencia CC BY-NC-ND (http://creativecommons.org/licenses/by-nc-nd/4.0/). 


\section{Introduction}

Approximately one-third of the population in intensive care units is in a state of circulatory shock, whose rapid recognition is important to avoid tissue injury and death" ${ }^{1}$.

The shock state has usually been categorized according to its cause ${ }^{2}$. Septic shock is the most severe manifestation of sepsis with an approximate mortality rate of $30 \%$; its incidence in patients admitted to intensive care units varies from 6 to $14 \%^{3-5}$. The cardiogenic shock commonly described in patients with acute myocardial infarction (AMI) has an incidence of $6-9 \%$ and its frequency has remained constant during the past decades with an approximate mortality rate of $50 \%{ }^{6}$.

There is little doubt about the physiopathological mechanisms of the different types of circulatory shock originally described by Weil and Shubin, however in the clinical practice at cardiac care units, it can be difficult to differentiate one mechanism from the other, which can hinder the treatment ${ }^{7}$.

This article aims to better understand the hemodynamic mechanisms responsible for the shock according to the practical approach proposed by Gonzalez et al. ${ }^{8}$

\section{Shock mechanism}

Shock is a state that compromises life, defined by a circulatory failure in which there is loss of the physiological balance between the oxygen delivery $\left(\mathrm{DO}_{2}\right)$ and the oxygen uptake $\left(\mathrm{VO}_{2}\right)$ conditioning an anaerobic metabolism and cellular hypoxia ${ }^{7}$. The reduction of cardiac output and/or peripheral resistances is finally translated into an increase in oxygen extraction, with the consequent decrease in central venous oxygen saturation $\left(\mathrm{SvO}_{2}\right)$, which may even occur before the elevation of serum lactate. Elevation of lactate is directly proportional to the prognosis, initial values above $4.0 \mathrm{mmol} / \mathrm{L}$ and negative clearance are related to higher mortality ${ }^{9-11}$.

Circulatory shock can be classified into four subtypes according to its mechanism: (1) loss of vascular tone that causes poor distribution of blood flow (distributive shock); (2) failure of the cardiac pump function (cardiogenic shock); (3) loss of circulating volume with decreased venous return (preload) either by internal or external losses (hypovolemic shock); and (4) obstruction caused by a pulmonary embolism, tension pneumothorax, or cardiac tamponade (obstructive shock). These shock states are not mutually exclusive and can be found simultaneously. Typically, the last three states are characterized by a low cardiac output with increased peripheral vascular resistance, while in the distributive shock cardiac output is normal or high with loss of the vascular tone $e^{2,6,7}$.

\section{Evaluation of circulatory shock}

The diagnosis of circulatory shock is based on clinical components, hemodynamics, and biochemical data of tissue hypoxia. There are three types of "clinical windows" described by Vincent et al. through which we can see the effects of the altered tissue perfusion: the skin (coldness, cyanosis, and pallor), kidneys (oliguria with urinary output $<0.5 \mathrm{~mL} / \mathrm{kg} / \mathrm{h}$ ), and the central nervous system (neurological alterations including drowsiness, disorientation, and confusional state). The presence of hypotension defined in the state of shock as a mean arterial pressure $<65 \mathrm{mmHg}$, systolic blood pressure < $90 \mathrm{mmHg}$ or a decrease $>40 \mathrm{mmHg}$ of baseline blood pressure is a component of shock ${ }^{2,12}$.

The two main biochemical markers of tissue hypoperfusion are the serum lactate and the central venous oxygen saturation $\left(\mathrm{SvO}_{2}\right)$ obtained in a blood sample from the cavoatrial junction ${ }^{9,11,12}$.

The evaluation of the circulatory shock, as mentioned above, can be done in a simple way by physical examination, evaluating the "windows" in search of hypoperfusion data; nevertheless, an integral approach is necessary for conjunction with the biochemical variables, and hemodynamic parameters Fig. 1,13.

\section{Hemodynamic profiles}

Once the circulatory shock has been identified, it is necessary to determine the main responsible mechanism. The clinical context and the physical examination are important, but in complex situations, as it happens in cardiac care units, reaching a correct diagnosis is usually a challenge. Each shock mechanism has different hemodynamic characteristics that allow us to identify them (Table 1).

\section{Hypovolemic shock}

It is characterized by a significant loss of intravascular volume resulting in an increase of sympathetic tone causing selective vasoconstriction of the skin, muscles, and splanchnic circulation to maintain venous return as well as cardiac output. If the intravascular volume loss continues, there is a decrease in the preload and subsequently in the cardiac output ${ }^{12,13}$. 
Table 1. Hemodynamic profile in different shock states

\begin{tabular}{|c|c|c|c|c|}
\hline Shock subtype & Cardiac index & $\begin{array}{l}\text { Systemic vascular } \\
\text { resistances }\end{array}$ & $\begin{array}{l}\text { Central venous } \\
\text { pressure }\end{array}$ & $\begin{array}{l}\text { Pulmonary capillary } \\
\text { wedge pressure }\end{array}$ \\
\hline Cardiogenic LV & Low & $\begin{array}{l}\text { High (Can be low in } \\
25 \% \text { of cases) }\end{array}$ & High & High \\
\hline Cardiogénic RV & Low & High & High & Low \\
\hline Hypovolemic & Low & High & Low & Low \\
\hline $\begin{array}{l}\text { Obstructive } \\
\text { Pulmonary embolism } \\
\text { Tamponade } \\
\text { Distributive }\end{array}$ & $\begin{array}{l}\text { Low } \\
\text { Low } \\
\text { Normal/High (Can be low in the late } \\
\text { phase of sepsis) }\end{array}$ & $\begin{array}{l}\text { High } \\
\text { High } \\
\text { Low }\end{array}$ & $\begin{array}{l}\text { High } \\
\text { High } \\
\text { Low }\end{array}$ & $\begin{array}{l}\text { Low } \\
\text { High } \\
\text { Low }\end{array}$ \\
\hline
\end{tabular}

RV: right ventricular; LV: left ventricular.
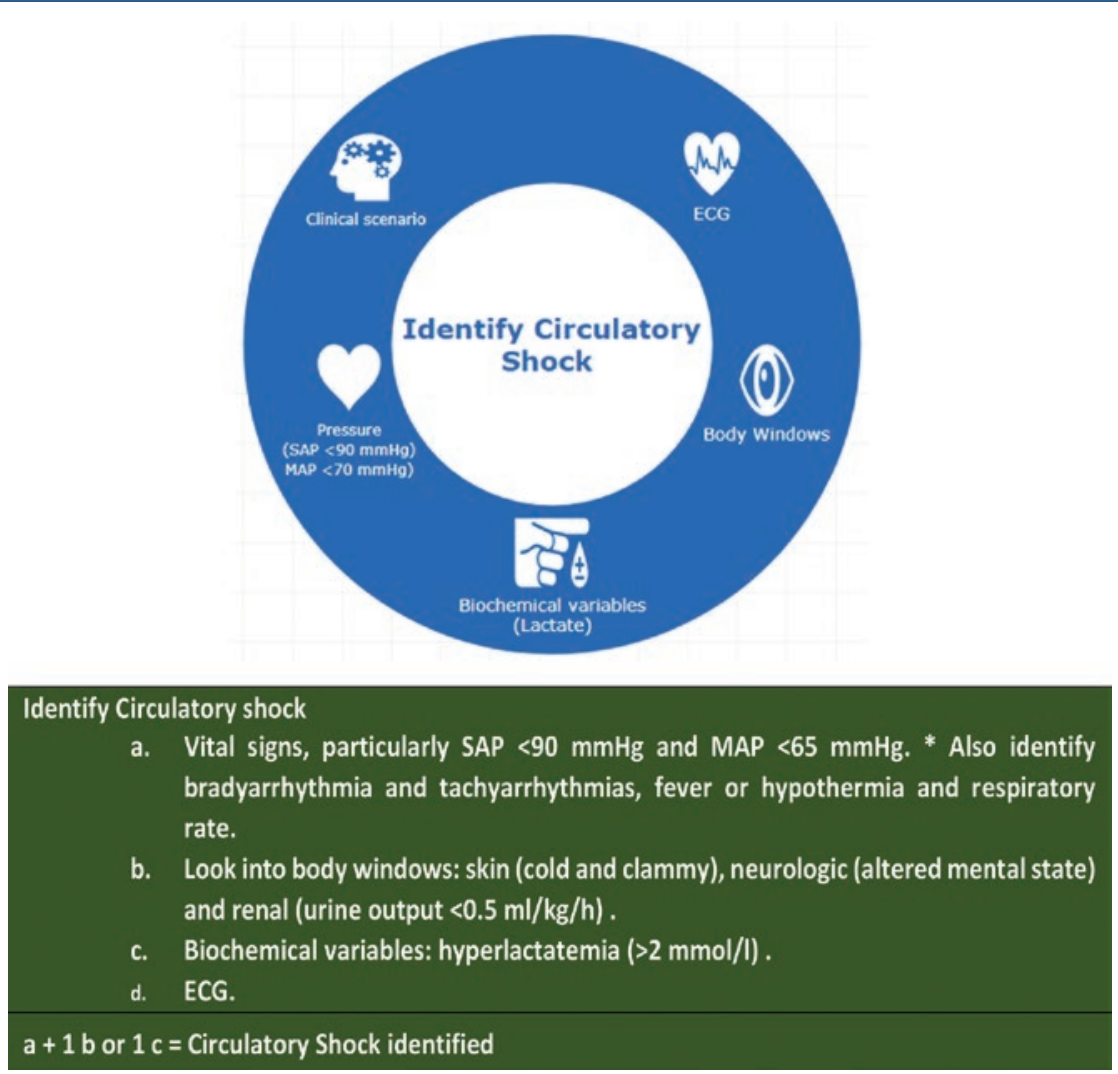

Figure 1. Identification of circulatory shock.

\section{Cardiogenic shock}

Any cause of left or right ventricular dysfunction or both can lead to cardiogenic shock, characterized by pump failure with increased ventricular filling pressures, and a low cardiac output with increased systemic vascular resistance ${ }^{14}$.

\section{Obstructive shock}

It is caused by the inability to maintain adequate cardiac output despite normal intravascular volume and intrinsic myocardial function. An obstruction due to a pulmonary embolism, tension pneumothorax or cardiac tamponade causes a decreased cardiac output, an 


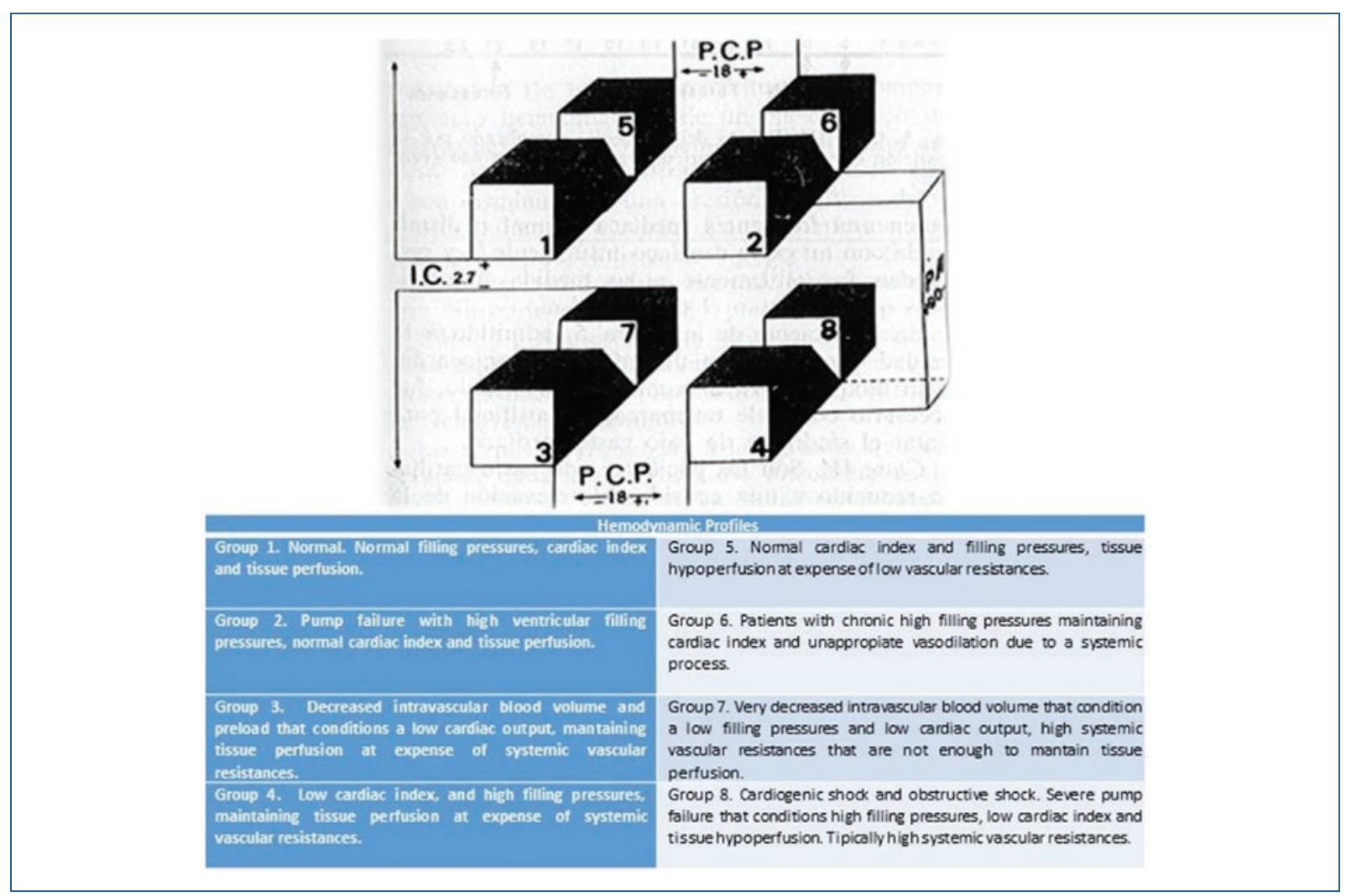

Figure 2. Hemodynamic profile in cardial care units (modified from Los problemas hemodinámicos en el infarto del miocardio. Arch Card Mex. 1980;50(3):319-26, with authorization from Dr. Jesus Antonio González Hermosillo).

elevation in systemic vascular resistances and variable wedge pressure (pulmonary artery wedge pressure [PCWP]) depending on the etiology ${ }^{15,16}$.

\section{Distributive shock}

It is caused by the loss of vascular tone with the resulting maldistribution of blood flow due to sepsis, anaphylaxis, or spinal cord injuries. Usually, the cardiac output is normal or high and a normal PCWP ${ }^{13,15}$.

In 1980, Gonzalez et al. proposed a three-dimensional scheme to classify hemodynamic profiles according to three determinant variables: filling pressures, cardiac index and unlike the Forrester scale, adding the arterial pressure as a third variable with which they obtain eight possible hemodynamic states with different clinical expression and therapeutic approach, Groups 2-4 (systolic arterial pressure $>90 \mathrm{mmHg}$ ) correspond to patients with hemodynamic compromise but normal arterial pressure due to different compensatory mechanisms, these profiles were previously known as pre-shock, and if treated timely and properly can have a better prognosis; otherwise they will develop circulatory shock (Groups 5-8) ${ }^{8}$.
Although this classification was initially aimed to assess the hemodynamic status during AMI, currently with the availability of new monitoring devices which allow a more accurate measurement of these and other hemodynamic parameters, we consider that its adjustment may be useful to classify the different hemodynamic states observed in the cardiac care units (Fig. 2). An adequate initial assessment of the hemodynamic status can be achieved with the clinical examination and monitoring of certain basic hemodynamic parameters (heart rate, blood pressure, central venous pressure, respiratory variables, $\mathrm{SvcO}_{2}$, electrocardiography, lactate, and urine output). However, when this fails, there are other monitoring modalities that guide the management of fluids and the inotropic/vasopressor support (PCWP, stroke volume variation, cardiac output, extravascular water, etc.) (Table 2).

\section{Hemodynamic monitoring devices}

Although still the gold standard, less used, the pulmonary artery catheter was introduced in 1970 by Swan, Ganz and Forrester as a method for the 
Table 2. Hemodynamic parameters

\begin{tabular}{|l|c|c|}
\hline Parameter & Equation & Normal Values \\
\hline $\mathrm{SaO}_{2}$ (Arterial oxygen saturation) & & $95-100 \%$ \\
\hline $\mathrm{SvCO}_{2}$ (Central venous oxygen saturation) & Systolic diastolic & $70 \%$ \\
\hline Arterial blood pressure (TA) & & $90-140 \mathrm{mmHg}$ \\
& $60-90 \mathrm{mmHg}$ \\
\hline Pulmonary artery wedge pressure (PCWP) & HR $\times$ SV/1000 & $5-12 \mathrm{mmHg}$ \\
\hline Cardiac output (CO) & $\mathrm{CO} / \mathrm{BS}$ & $4.0-8.0 \mathrm{~L} / \mathrm{min}$ \\
\hline Cardiac index (Cl) & $\mathrm{CO} / \mathrm{HR} \times 1000$ & $2.2-4.0 \mathrm{~L} / \mathrm{min} / \mathrm{m}^{2}$ \\
\hline Stroke volume & $\mathrm{CO} / \mathrm{HR} \times 1000 / \mathrm{BS}$ & $60-100 \mathrm{~mL} / \mathrm{beat}$ \\
\hline Systolic volume index (SVI) & & $33-47 \mathrm{~mL} / \mathrm{m}^{2} / \mathrm{beat}$ \\
\hline Systolic volume variation (SVV) & (maxSV - minSV)/Mean SV $\times 100$ & $10-15 \%$ \\
\hline Right atrium pressure (RAP) & $80 \times$ (MAP - RAP)/CO & $0-5 \mathrm{mmHg}$ \\
\hline Systemic vascular resistances (RVS) & & $800-1200 \mathrm{dynas} / \mathrm{s} / \mathrm{cm}$ \\
\hline
\end{tabular}

Table 3. Hemodynamic monitoring devices

\begin{tabular}{|l|l|l|l|l|}
\hline Method & Examples & Calibration & Advantages & Disadvantages \\
\hline $\begin{array}{l}\text { Transpulmonary thermodilution } \\
\text { (moderately invasive) }\end{array}$ & $\begin{array}{l}\text { PiCCO } \\
\text { VolumeView } \\
\text { EV1000 } \\
\text { LiDCO }^{\circledR}\end{array}$ & Calibrated & $\begin{array}{l}\text { Intermittent and } \\
\text { continuous CO and } \\
\text { other variables }\end{array}$ & $\begin{array}{l}\text { Need of central venous and } \\
\text { arterial line }\end{array}$ \\
\hline $\begin{array}{l}\text { Pulse contour and pulse pressure } \\
\text { variation (minimally invasive). }\end{array}$ & $\begin{array}{l}\text { FloTrac/Vigileo } \\
\text { ProAOT } \\
\text { Pulsioflex } \\
\text { MostCare } \\
\text { LiDCOrapid }\end{array}$ & Non-calibrated & Continuos CO & $\begin{array}{l}\text { Lack accuracy in unstable } \\
\text { patients or during use vasoactive } \\
\text { drugs }\end{array}$ \\
\hline
\end{tabular}

measurement of cardiac output, and it is with this that several studies have compared the majority of the new devices and techniques used ${ }^{17}$.

Recently, multiple devices have been developed allowing cardiac output and other hemodynamic parameters to be obtained in real time. Among many others, these systems include $\mathrm{PiCCO}^{\circledR}$, MostCare $\mathrm{Vygon}^{\circledR}$, FloTrac Vigileo ${ }^{\circledR}$ Echocardiogram, and Lung Ultrasound, which provide information on preload, afterload and contractility variables, all aimed at improving both cardiac output and tissue perfusion ${ }^{18,19}$.

Non-invasive monitoring devices can be moderately invasive or minimally invasive. The moderately invasive devices (require arterial catheter plus a central venous line) offer the advantage of a continuous analysis of cardiac output by means of the thermodilution principle and minimally invasive devices (only require an arterial catheter) allow an uncalibrated analysis (FloTrac ${ }^{\circledR} /$ Vigileo $^{\circledR}$, LiDCOrapid $^{\circledR}$, ProAQT $^{\circledR} /$ Pulsiflex $^{\circledR}$ ).

With transpulmonary thermodilution, it is possible to determine the cardiac output, extrapulmonary extravascular water, pulmonary vascular permeability, and index of cardiac function and end-diastolic volume (Table 3) $)^{20-21}$.

\section{Pulmonary artery catheter}

Catheter introduced by jugular, subclavian, or femoral access in the pulmonary artery. It allows the measurement of the PCWP, indicative of the filling pressures of the left atrium; it also allows the measurement of cardiac output by thermodilution, calculation of pulmonary and systemic vascular resistance as well as ventricular systolic volume. It is not considered a dynamic monitoring device and has wide inter-observer variability ${ }^{17,21}$. 
Table 4. Echo parameters for the assessment of circulatory shock

\begin{tabular}{|c|c|c|}
\hline Cardiac output & LVOT Area $\times$ VTI $($ LVOT $) \times$ HR & $\begin{array}{l}\text { LVOT Area }=(\text { aortic annulus in } \mathrm{cm})^{2} \times 0.785 \\
\text { VTI LVOT = Sample volume of the pulsed Doppler } 1 \mathrm{~cm} \text { before the } \\
\text { valve in apical approach three or five chambers, tracing with an } \\
\text { electronic pencil the Doppler spectrum of the aortic flow }\end{array}$ \\
\hline Fluid responsiveness & $\begin{array}{l}\text { Spontaneous breathing } \\
\text { Invasive mechanical ventilation }\end{array}$ & $\begin{array}{l}\text { IVC collapsability index }>36 \% \text { or IVC }<10 \mathrm{~mm} \\
\text { IVC distensibility index }>18 \% \\
\text { IVC variability } 12 \% \\
\text { VTI and LVOT peak velocity variability }>12 \%\end{array}$ \\
\hline Filling pressures & $\begin{array}{l}\text { Right atrium pressure } \\
\text { Left Atrium pressure }\end{array}$ & $\begin{array}{l}\text { IVC }<21 \mathrm{~mm} \text { and }>50 \% \text { collapse }=3 \mathrm{mmHg} \\
\text { IVC }>21 \mathrm{~mm} \text { and }<50 \% \text { collapse }=15 \mathrm{mmHg} \\
\mathrm{IVC}<21 \mathrm{~mm} \text { and }<50 \% \text { collapse or }>21 \mathrm{~mm} \text { and } \\
>50 \% \text { collapse }=8 \mathrm{mmHg} \\
\text { E/e' }>14 \text { (High) }\end{array}$ \\
\hline Diastolic function & $\begin{array}{l}\text { Impaired relaxation } \\
\text { Pseudonormal } \\
\text { Restrictive }\end{array}$ & $\begin{array}{l}\text { Filling pressures - } \\
\text { Filling pressures +/- } \\
\text { Filling pressures + }\end{array}$ \\
\hline Left ventricle & EF (Simpson) & $\begin{array}{l}\text { Men }>52 \% \\
\text { Women }>54 \%\end{array}$ \\
\hline Right ventricle & $\begin{array}{l}\text { Longitudinal function } \\
\text { Global systolic function }\end{array}$ & $\begin{array}{l}\text { TAPSE }>17 \\
\mathrm{~S}^{\prime}>9.5 \\
\text { FAC }>35 \%\end{array}$ \\
\hline Lung hemodynamics & $\begin{array}{l}\text { PASP } \\
\text { mPAP } \\
\text { PVR }\end{array}$ & $\begin{array}{l}\text { TR gradient }+ \text { RAP } \\
90-(0.62 \times \text { RVOT acceleration time }) \\
(\text { peak TR velocity/RVOT VTI } \times 10+0.16\end{array}$ \\
\hline
\end{tabular}

LVOT: left ventricular outflow tract; VTI: velocity-time integral; HR: heart rate; IVC: inferior vena cava; RVOT: right ventricular outflow tract; RAP: right atrial pressure; TR: tricuspid regurgitation; PVR: pulmonary vascular resistance; mPAP: mean pulmonary artery pressure; PASP: pulmonary artery systolic pressure.

\section{PiCCO $^{\circledR}$ system}

It uses a central venous catheter and an arterial line that provides continuous measurement of cardiac output by thermodilution using a bolus of cold fluid injected through the central line. By means of an algorithm based on the analysis of the arterial pulse wave, continuous monitoring of cardiac output, and systolic volume is possible. The variation of the systolic volume and the variation of the pulse pressure are variables that can guide the response to fluid, although they are limited to completely sedated patients, under invasive mechanical ventilation and with the absence of arrhythmias. Unlike the pulmonary artery catheter, it is less invasive, allows to measure cardiac output continuously and assess the response to fluids ${ }^{19,22}$.

\section{FloTrac/Vigileo ${ }^{\circledR}$ system}

Device uses the variation of pulse pressure and vascular tone to calculate the systolic volume and cardiac output $^{19,20,22}$.

\section{Transthoracic echocardiogram}

Useful to measure cardiac output by calculating the velocity-time integral of the left ventricular outflow tract by Pulsed Doppler, it is a dependent operator procedure. It is also useful to asses volume responsiveness. Table 4 summarizes the parameters that can be calculated using echocardiography ${ }^{23}$.

\section{Lung ultrasound}

It is a tool that has been proposed for the assessment of circulatory shock using the Fluid Administration Limited by Lung Sonography-protocol first searching for pericardial fluid, right ventricle enlargement and tension pneumothorax (obstructive shock), if none of these is identified, the next step is to search for $\mathrm{B}$-lines whose presence indicates pulmonary edema and cardiogenic shock as the likely cause. On the contrary, its absence, with a normal sonographic lung surface and fluid responsiveness indicate hypovolemic shock ${ }^{24}$ Fig. 3. 


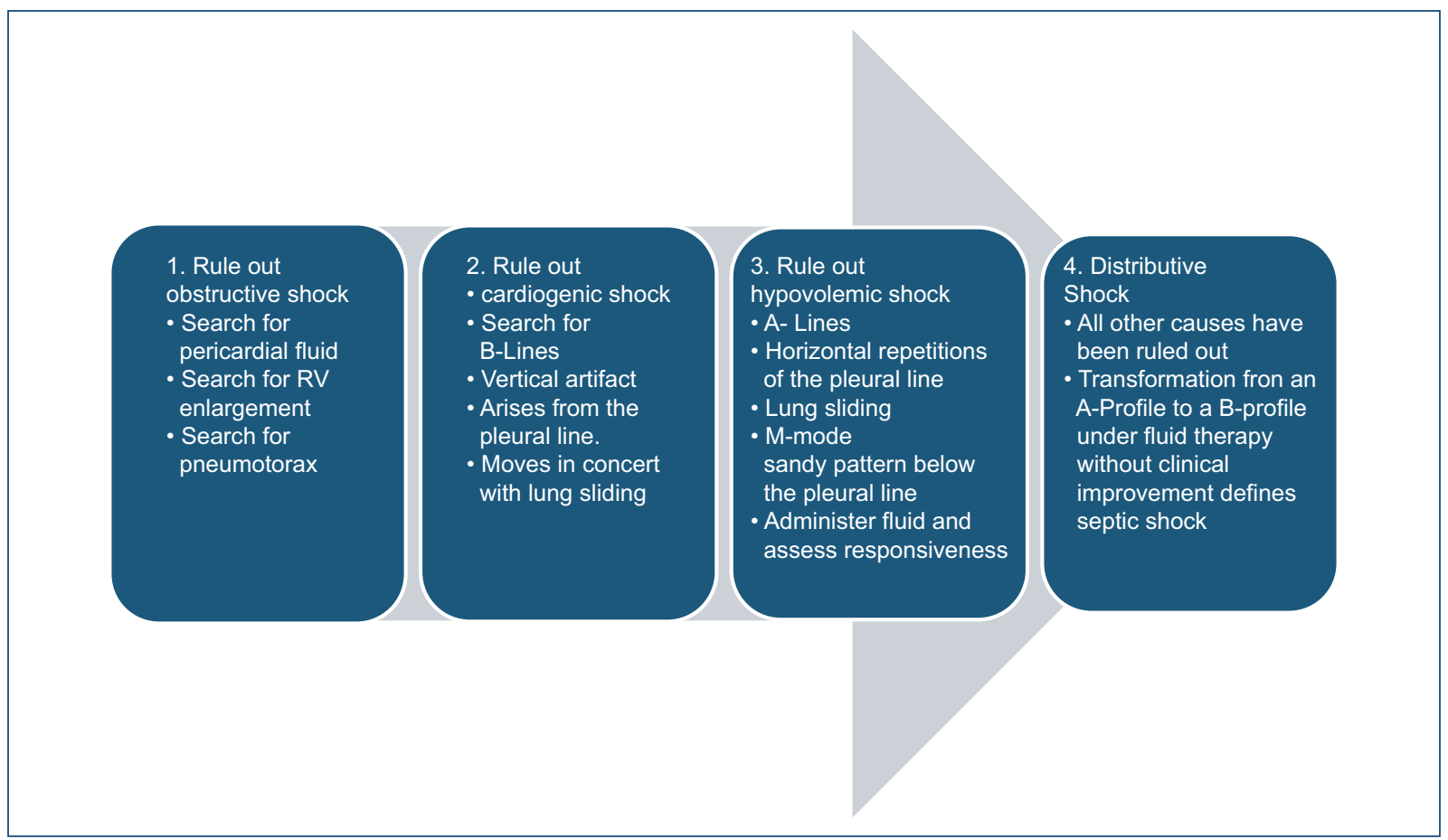

Figure 3. The Fluid Administration Limited by Lung Sonography-protocol.

Table 5. Pharmacologic and non-pharmacologic intervention

\begin{tabular}{|c|c|c|c|c|c|c|}
\hline Class & $\begin{array}{c}\text { Tissue } \\
\text { perfusion }\end{array}$ & CI & $\begin{array}{c}\text { Filling } \\
\text { pressures }\end{array}$ & Example & Causes & Recommendation \\
\hline 1 & $\rightarrow$ & $\rightarrow$ & $\rightarrow$ & Normal & NA & Requirements \\
\hline 2 & $\rightarrow$ & $\rightarrow$ & $\uparrow$ & HFpEF & Multiple & $\begin{array}{l}\text { Diuretic } \\
\text { Vasodilator } \\
\text { NIVM }\end{array}$ \\
\hline 3 & $\rightarrow$ & $\downarrow$ & $\rightarrow$ & Hypovolemia & $\begin{array}{l}\text { Losses } \\
\text { (GI, diuretics, bleeding, etc.) }\end{array}$ & $\begin{array}{l}\text { Crystalloids } \\
\text { Blood }\end{array}$ \\
\hline 4 & $\rightarrow$ & $\downarrow$ & $\uparrow$ & HFrEF & Multiple & $\begin{array}{l}\text { Diuretic } \\
\text { Vasodilator } \\
\text { NIMV } \\
\text { STVAD } \\
\text { LTVAD }\end{array}$ \\
\hline 5 & $\downarrow$ & $\rightarrow$ & $\rightarrow$ & Distributive shock & $\begin{array}{l}\text { Sepsis } \\
\text { Anaphylaxis } \\
\text { Spinal cord injury }\end{array}$ & Vasopressor \\
\hline 6 & $\downarrow$ & $\rightarrow$ & $\uparrow$ & $\begin{array}{l}\text { Valvular heart disease/ } \\
\mathrm{HF}+\text { vasodilation }\end{array}$ & Mix & Vasopressor +/- Inotropic \\
\hline 7 & $\downarrow$ & $\downarrow$ & $\rightarrow / \downarrow$ & Hypovolemic shock & $\begin{array}{l}\text { Losses } \\
\text { (Surgery, diuretics, bleeding) }\end{array}$ & $\begin{array}{l}\text { Vasopressor } \\
\text { Crystalloid } \\
\text { Blood }\end{array}$ \\
\hline 8 & $\downarrow$ & $\downarrow$ & $\uparrow$ & Cardiogenic shock & $\begin{array}{l}\text { MI } \\
\text { Valvular } \\
\text { Arrythmia }\end{array}$ & $\begin{array}{l}\text { Inotropic } \\
\text { PCI } \\
\text { IABP } \\
\text { Pacemaker } \\
\text { VAD ST or LT }\end{array}$ \\
\hline
\end{tabular}

GI: gastrointestinal; IABP: intra-aortic balloon pump; PCI: percutaneous coronary intervention; STVAD: short-term ventricular assist devices; LTVAD: long-term ventricular assist device. 


\section{Goal directed therapy}

The modification of all these variables (oxygen transport, preload, afterload, and vascular tone) is possible through pharmacological and non-pharmacological interventions ${ }^{19,20}$. The initial management of the shock should include ventilatory assistance, fluid resuscitation, and the use of vasoactive drugs according to the different hemodynamic profiles; occasionally, when these strategies fail and in the proper context it is necessary the use of circulatory assistance devices (Intra-aortic Balloon Pump, Extracorporeal Membrane Oxygenation, CentriMag, Impella, etc.) (Table 5).

\section{Conclusion}

The importance of the different tools is to be able to provide a better and easier assessment of the different hemodynamic profiles in circulatory shock. The cardiologist must have the ability to identify and assess different hemodynamic parameters in initial stages before circulatory shock; the failure to recognize and treat coexisting etiologies and contributors to the state of shock can lead to poor prognosis.

\section{Conflicts of interest}

None declared.

\section{Ethical disclosures}

Protection of human and animal subjects. The authors declare that no experiments were performed on humans or animals for this study.

Confidentiality of data. The authors declare that no patient data appear in this article.

Right to privacy and informed consent. The authors declare that no patient data appear in this article.

\section{References}

1. Sakr Y, Reinhart K, Vincent JL, Sprung CL, Moreno R, Ranieri VM, et al. Does dopamine administration in shock influence outcome? Results of the sepsis occurrence in acutely ill patients (SOAP) study. Crit Care Med. 2006;34:589-97.
2. Vincent JL, De Backer D. Circulatory shock. N Engl J Med. 2013;369: 1726-34.

3. Jawad I, Lukšić I, Rafnsson SB. Assessing available information on the burden of sepsis: global estimates of incidence, prevalence and mortality. J Glob Health. 2012;2:010404.

4. Antonelli M, Levy M, Andrews PJ, Chastre J, Hudson LD, Manthous C, et al. Hemodynamic monitoring in shock and implications for management. International consensus conference, Paris, France, 27-28 April 2006. Intensive Care Med. 2007;33:575-90.

5. Rivers E, Nguyen B, Havstad S, Ressler J, Muzzin A, Knoblich B, et al Early goal-directed therapy in the treatment of severe sepsis and septic shock. N Engl J Med. 2001;345:1368-77.

6. Babaev A, Frederick PD, Pasta DJ, Every N, Sichrovsky T, Hochman JS, et al. Trends in management and outcomes of patients with acute myocardial infarction complicated by cardiogenic shock. JAMA. 2005; 294:448-54.

7. Vincent JL, Ince C, Bakker J. Clinical review: circulatory shock an update: a tribute to professor Max Harry Weil. Crit Care. 2012;16:239.

8. Gonzalez JA, Cardenas M, Sobrino A, Verdejo J. Los problemas hemodinámicos en el infarto al miocardio. Arch Inst Cardiol Mex. 1980; $50: 521$.

9. Reinhart K, Kuhn HJ, Hartog C, Bredle DL. Continuous central venous and pulmonary artery oxygen saturation monitoring in the critically ill. Intensive Care Med. 2004;30:1572-8.

10. Shapiro NI, Howell MD, Talmor D, Nathanson LA, Lisbon A, Wolfe RE, et al. Serum lactate as a predictor of mortality in emergency department patients with infection. Ann Emerg Med. 2005;45:524-8.

11. Rivers EP, Elkin R, Cannon CM. Counterpoint: should lactate clearance be substituted for central venous oxygen saturation as goals of early severe sepsis and septic shock therapy? No. Chest. 2011; 140:1408-13.

12. Hernandez G, Castro R, Romero C, de la Hoz C, Angulo D, Aranguiz I, et al. Persistent sepsis-induced hypotension without hyperlactatemia: is it really septic shock? J Crit Care. 2011;26:435.e9-14.

13. Weil MH, Shubin H. Proposed reclassification of shock states with special reference to distributive defects. Adv Exp Med Biol. 1971;23:13-23.

14. Menon V, White H, LeJemtel T, Webb JG, Sleeper LA, Hochman JS, et al. The clinical profile of patients with suspected cardiogenic shock due to predominant left ventricular failure: a report from the SHOCK trial registry. Should we emergently revascularize occluded coronaries in cardiogenic shock? J Am Coll Cardiol. 2000;36:1071-6.

15. Pinsky MR. Hemodynamic evaluation and monitoring in the ICU. Chest. 2007:132:2020-9.

16. Pinsky MR. Heart-lung interactions. Curr Opin Crit Care. 2007;13:528-31.

17. Swan HJ, Ganz W, Forrester J, Marcus H, Diamond G, Chonette D, et al. Catheterization of the heart in man with use of a flow-directed balloon-tipped catheter. N Engl J Med. 1970;283:447-51.

18. Adler AC, Sharma R, Higgins T, McGee WT. Hemodynamic assessment and monitoring in the intensive care unit: an overview. Enliven $\mathrm{J}$ Anesthesiol Crit Care Med. 2014:1:10.

19. Jhanji S, Dawson J, Pearse RM. Cardiac output monitoring: basic science and clinical application. Anaesthesia. 2008;63:172-81.

20. García X, Mateu L, Maynar J, Mercadal J, Ochagavía A, Ferrandiz A, et al. Estimación del gasto cardíaco. Utilidad en la práctica clínica. Monitorización disponible invasiva y no invasiva. Med Intensiva. 2011; 35:555-61.

21. Squara $P$, Bennett $D$, Perret $C$. Pulmonary artery catheter: does the problem lie in the users? Chest. 2002;121:2009-15.

22. Hofer CK, Senn A, Weibel L, Zollinger A. Assessment of stroke volume variation for prediction of fluid responsiveness using the modified FloTrac and PiCCoplus system. Crit Care. 2008;12:R82.

23. Lancellotti P, Price S, Edvardsen T, Cosyns B, Neskovic AN, Dulgheru R et al. The use of echocardiography in acute cardiovascular care: recommendations of the European association of cardiovascular imaging and the acute cardiovascular care association. Eur Heart J Cardiovasc Imaging. 2015;16:119-46.

24. Lichtenstein D. FALLS-protocol: lung ultrasound in hemodynamic assessment of shock. Heart Lung Vessel. 2013;5:142-7. 